\title{
Bartłomiej Majkrzak
}

\section{Bruno Stein's Organ Music in the Context of Pedagogical and Musical Activity}

\section{Abstract}

The purpose of this article is to present the life and organ work of Bruno Stein. The preparation for teaching was very important in Prussia, as it somehow traced a path of development for young people not only willing to be teachers but also musicians in the future. Bruno Stein, when composing organ preludes, recognised this situation and simultaneously became a model teacher as well as a composer of reliable and solid artistic achievements. The crucial element constituting the core of this article is the analysis of the selected preludes for organ. Having taken these compositions into account, one can observe the artistic means that were used by the composer, explore their style and purpose. Apart from organ works, Bruno Stein composed many other vocal, instrumental and vocal-instrumental pieces.

\section{Keywords}

Bruno Stein, organ, teacher's seminar, church music 


\section{Introduction}

For many years the position of an organist in the Catholic Church was perceived as very prestigious. In the documents of the Church, it is underlined that music is an inevitable and at the same time integral element of the liturgy. Therefore, the musician should not only be properly educated but also sensitive to the sphere of sacrum. In the history of Church music, there are many excellent organists, who combined their function with pedagogical work, or even composition.

The following article is devoted to Bruno Stein, the organist of Silesian origin, teacher and composer. Raised up in the Catholic family, he followed the path initiated by his father Joseph. It could be asked in what aspect he was extraordinary among other church musicians. The fact is that, despite his short life, he perfectly accomplished his task. He was not only the authority for the young adepts of this difficult art, but primarily, he created the works which are the examples of a proper compositional craft and are characterised by the harmonic and contrapuntal correctness.

This article is only an introduction to the research on the output of the artist who died in 1915. At this moment, the diversity of his compositions should be mentioned. In his output, there are not only organ works, but primarily vocal and vocal-instrumental masses.

The events of the war and lack of existing documentation are not in favour of preserving the memory of the composer. Many of his works were lost or have not been found yet. Nevertheless, thanks to the help of the people concerned about the tradition, wishing to re-discover these beautiful gems of sacred music, so far most of the organ works of Stein have been gathered, what is, without doubt, a big progress.

\section{Bruno Stein-life and art}

Bruno Maria Josef Stein was born on the 27th of June 1873 in Olesno (in German Rosenberg). He was a son of Joseph Stein-a composer, musician and pedagogue. He owed rudimental development of his craft to his father, a respected musician. He learnt from, among 
others, Ignaz Reimann, Julius Schneider and Albert Löschhorn. ${ }^{1}$ He gained further knowledge on his own. Similarly to his father, he was a good instrumentalist, talented improvisator and composer. Also, the whole family of Stein had significant musical abilities. It is worthy to mention the siblings Franz and Margarete, who also took part in developing music in Silesia in the field of composition, singing, didactic method.

Despite financial difficulties, Bruno Stein gained education as a teacher in Olesno, and then in the years 1896-1897 he studied at the Royal Academic Institute of Church Music in Berlin. ${ }^{2}$ As a pedagogue, he worked in Grotków, ${ }^{3}$ and then in 1897 he was nominated for a position of a teacher in Bydgoszcz, where he taught in a teacher's seminary and conducted the choir at Singing Association "Eintracht". He stayed there until his death. ${ }^{4}$ Thanks to composing the mass for male voices and organs he was nominated as a member of Royal Philharmonic Academy of Bologna. He died prematurely at the age of forty-two. He was buried at the cemetery in Oleśno.

He was a modest and helpful person, exactly like his father, but withdrawn, inaccessible and fascinated by music. He was versatile and especially interested in literature and theatre. ${ }^{5}$

Church music was very important for Stein. During his short life, he composed almost seventy-five works: masses (including requiem), oratorios, Latin and German church songs, organ pieces, works for male choirs (with instruments or a cappella).

The composer was honoured with the award of the Philharmonic Academy in Bologna, which he received for Cäcilienmesse Op. 5 for male choir and organ. The success of the work was confirmed by its next editions.

1 A. Glauer, 150 Jahre-eine Zeitreise, Opole 2012, pp. 332-335. Vide also: B. Speer, Stein, [in:] Schlesisches Musiklexikon, L. Hoffmann-Erbrecht (ed.), Augsburg 2001, p. 716 .

2 G. Strecke, Josef und Bruno Stein, zwei oberschlesischen Kirchenkomponisten, "Der Oberschlesier" 11 (1929), pp. 821-825.

3 German: Grottkau. In 1945, after joining the town to Poland, the official name was Grotków (vide: Dz.U. 1945, No. 33, sign. 196). Currently Grodków.

4 F. Hamann, Die Musikerziehung an den ehemaligen Lehrerseminaren in Nieder- und Oberschlesien, Ost- und Westpreußen, Pommern und Posen nebst Biographien ihrer Musiklehrer (SML), Dortmund 1976, p. 154. Vide also: A. Glauer, op. cit., p. 337.

5 Ibid., p. 339. 
The setting of the mass cycles are one of the most important compositions in Stein's musical output. The example of this can be Missa brevis Op. 7 for two voices and organ (ed. CoppenrathRegensburg). In Missa decima Op. 37 the organ accompanies four male voices. Festmesse Op. 49 (ed. Kothe-Leobschütz) is a work, in which mixed choir with organ predominates. The culminating point in Bruno Stein's mass output is five-voice Missa Op. 55. As Gerhard Strecke claims, the particular voices harmonise together in such a good way that it impresses the listener very much and proves the undeniable talent of the composer. ${ }^{6}$

Motets written by Stein did not only prove that there was the need for works of this type but also they allowed the creator to use the vast amount of forms of sacred music written over the centuries. In this field, Weihnachtsmotet Op. 63 for five-voice choir appeared to be the best. The score of this composition was published in the journal "Der Oberschlesier" No. 11 (1929).

Among the secular compositions of Stein there are, among others, the song for male choir Der Wald Op. 30 No. 1 as well as setting of Schiller's text, Wir wollen sein ein einig Volk von Brüdern (William Tell) for male voice with the accompaniment of the small wind orchestra. What should be also recognised is his school sing book-the song cycle Lieder der Liebe for solo voice with the accompaniment of the piano. ${ }^{7}$

Works that Bruno Stein wrote had an impact on the enrichment of the liturgy of a mass, encouraged the listeners to pray and influenced the sphere of a spiritual beauty of a man. The discussed artist dedicated himself not only to the activity in the area of church music, but also to the musical development of young people. Thanks to the pedagogical activity, he influenced developing the musical sensitivity of a young generation.

\section{Education at Royal Teacher's Seminaries}

Teacher's seminaries functioned the most vividly in Prussia and Prussian Partition. In this area, Royal Teacher's Seminaries (Königliches Lehrerseminar) were created, both Catholic and Lutheran. The main difference between them consisted of the fact that only

6 G. Strecke, op. cit., pp. 821-825.

7 Ibid., pp. 821-825. 
German-originating people could attend Lutheran seminary, while the participants of Catholic seminary were both Polish and German people. Education in these centres took three years, but it has to be preceded by the preparation (Präparandenstalt), ${ }^{8}$ which also took three years. The candidate for participating in the seminary had to have musical abilities as well as appropriate psychological predispositions. Moreover, the knowledge of languages was obligatory, both German and Poland (Catholic seminary). The candidate handed in seven documents to the headmaster:

- Curriculum vitae;

- Baptism certificate;

- First Communion certificate;

- Health condition certificate;

- Two certificates of previous education;

- The declaration of a father to pay for him during the education. ${ }^{9}$

A student of a seminary gained wide knowledge in terms of humanities, mathematics, natural science and arts. High level of education was to guarantee the skills that are necessary for teaching. The fact that pupils lived in the dormitories was significant in the whole process - the constant care of the pedagogues allowed to monitor the students permanently. Youths together with teachers actively participated in the social and cultural life of a city, taking responsibility for preparation of the church and state festivities. Beside these responsibilities, there were internships, lasting during the whole education. Because of that, there were practice schools at the seminaries, where students taught classes monitored by their pedagogues. Graduates were certified teachers, entitled to teach at state schools. ${ }^{10}$

The low development of state education was a reason for diverse preparation of candidates for teacher's seminaries. Frequently, instead of obligatory eight years the candidates finished fewer classes.

8 F. Hamann, op. cit., p. 20.

9 J. Chrząszcz, Historia miast Pyskowice i Toszek, Gliwice 1994, pp. 141-144.

10 S.I. Możdżeń, Historia wychowania 1795-1918, Sandomierz 2006, p. 102. Vide also:

J. Chrząszcz, op. cit., pp. 170-171. 
Due to this, state governors met their expectations and organised preparatory classes at seminaries, having their own pedagogues.

Teacher's Präparandenstalt are nothing but preparatory classes, but expanded, improved, independent and adapted to new demands in common education. ${ }^{11}$

The need for new teachers was so great that every year there were more and more candidates to hold this function. Introductory exam took several days and consisted of the elements of Polish language and mathematics. Musical skills were also checked. ${ }^{12}$ After passed exam and three years of intense education in preparatory class, the lad was able to become a seminary participant.

Pedagogical programme of a teacher's seminary was different in particular partitions. The changes referred not only to the names of the classes but also their programme and number of hours. The works on arranging the unified way of preparation were conducted in the years 1914-1922. In 1926 it was modifiede.g. the amount of hours for artistic classes increased. ${ }^{13}$

After regaining Polish independence in 1918, the places of educating teachers were, through the act of the Polish Government (Dekret o kształceniu nauczycieli szkót powszechnych w Państwie Polskiem from the 7th of February 1919), the basic form of their preparation. The act established the system of educating teachers in the whole country. It stated that these places would be sustained by the state, separately for girls and boys.

A great number of young people joining the units responsible for educating teachers resulted in quick fulfilling the need for a pedagogical board. In 1932 Jędrzejewicz's reform led to the liquidation of teacher's seminaries, transforming them into pedagogical high schools. The basic difference between these two systems was in the fact that pedagogical high schools gave the possibility to continue

11 Ministerstwo Wyznań Religijnych i Oświecenia Publicznego [Ministry of Religions and Education], Preparandy nauczycielskie, Warszawa 1922, p. 13.

12 Ibid., p. 31.

13 E. Dereń, Kształcenia nauczycieli szkót powszechnych, https://sites.google.com/ site/ksztalcenienauczycieli/organizacja-ksztalcenia-nauczycieli/lata-1918-1939 [accessed: 18.03.2018]. 
studying at the university, and teacher's seminaries, despite the high level of educating, had not given this opportunity. ${ }^{14}$

\section{Music teaching}

As mentioned in the previous paragraph, the highest level of education was noted at the teacher's seminaries in Prussia and Prussian Partition. During education of future pedagogues the special attention was paid to the musical development. Music teacher held the function not only at school but also outside it. Properly prepared, they were often the conductors of school and city choirs and instrumental ensembles as well as organists in churches. The demands for young adepts of this difficult art were high, what allowed to educate the musical taste as well as gain competence in playing the musical instrument, music theory, and even composition. What confirms this fact is the publication of Fritz Hamann titled Die Musikerziehung an den ehemaligen Lehrerseminaren in Nieder- und Oberschlesien, Ost- und Westpreußen, Pommern und Posen nebst Biographien ihrer Musiklehrer (SML), containing information about music teachers working in teacher's seminaries located in Prussia and Prussian Partition from the 18th to the 2oth century. Among them, there are such excellent personas as Joseph Ignatz Schnabel, Karl Joseph Nachbar, Joseph Stein or his son Bruno Stein.

A young person, despite singing lessons as well as music theory and harmony, had to learn to play three musical instruments: violin, piano and organ. Seminaries had a good instrumental amenities: upright pianos to practice, grand pianos, wind and string instruments, frequently also organ. ${ }^{15}$ The role that the organ played is confirmed by preserved numerous preludes and settings of church songs, written by music teachers working in teacher's seminaries (V. Kotalla, K.J. Nachbar, B. Stein and others).

The programme of teaching the music subjects was interesting, as it was divided into theoretical classes (harmony, music theory, history of music) and practical ones (playing the musical instruments,

14 S.I. Możdżeń, Historia wychowania 1795-1918, Sandomierz 2006, p. 102.

15 F. Hamann, op. cit., p. 19. 
singing). As the example can serve Lehrplan from 1865 from one of the teacher's seminaries:

\begin{tabular}{|l|c|c|c|}
\hline \multirow{2}{*}{ Subject } & Year* & & \\
\cline { 2 - 4 } & $\mathbf{3}$ & $\mathbf{2}$ & $\mathbf{1}$ \\
\hline Singing & 3 & 2 & 2 \\
\hline Harmony and methodology & 1 & 2 & 1 \\
\hline Violin & 2 & 1 & 1 \\
\hline Piano & 1 & 0 & 0 \\
\hline Organ & 0 & 1 & 1 \\
\hline
\end{tabular}

Table 1: Teaching programme of music subjects.

*The first year of studying is marked as number 3, the last one as 1.

How did classes of the particular subjects look like? Singing lessons covered vocal exercises and learning the given chants, folk songs, motets, psalms and hymns. Singing in the school choir and the active participation in the liturgy of the mass, vespers and other religious festivities were very important. Harmony was taught together with elements of methodology concerning its teaching. The young person gained theoretical knowledge together with practical skills-discovering the principles of connecting triads, seventh chords, dominant chords, playing modulations, learning how to write organ chorales and preludes. Playing the musical instruments was the base of musical skills. The piano was treated as technical preparatory for the organ playing. The violin required practising passages, getting to know the canons of violin literature, solo and ensemble playing. The organ was the most important element of education. It was assumed that a graduate would be well prepared to hold the position of a teacher, cantor, organist. ${ }^{16}$

Royal Teacher's Seminaries were characterised by the high level of education. A student gained wide knowledge and numerous skills. It should be remembered that the number of hours in

16 Ibid., pp. 26-29. 
the programme would not be enough to achieve the high level. Playing the musical instrument, composition or harmonic exercises required continuous practice. Students had authorities that were teachers-many of them, as it was mentioned before, were recognised musicians and composers.

\title{
Organ preludes in Bruno Stein's output
}

\author{
...Kyrie and Gradual were sung in the Gregorian way. Although \\ Gradual, Tract and Dies irae are long, nobody was bored. Organ \\ preludes composed by [Joseph-B.M.] Stein, played between \\ parts of the mass, created the unity. ${ }^{17}$
}

As it is seen in the quotation above, music is an integral part of liturgy. Besides Gregorian chant and vocal music, the organ played an important role, which was recognised as first among all instruments. ${ }^{18}$ Its great masters were perfect improvisers, composers, and also pedagogues (this model is present also today). ${ }^{19}$ However, not all organists could play at the highest level. Young adepts, who through practising and studying masters' works could achieve the appropriate level of play, should be remembered.

The 19th and 2oth centuries in music were characterised by the presence of variable materials helpful for organists, what resulted in the high level of the organ music in liturgy. ${ }^{20}$ As in the previous centuries, teachers, practicing musicians, created such works. Among composers indicating extraordinary engagement in the development of church music there was also Bruno Stein.

17 F. Witt, Musica Sacra, Regensburg 1883, p. 16. It refers to liturgical mass for the dead celebrated on 25.10.1882 as a part of the Conference of Teachers at St Michael parish church in Oleśno. Vide also: A. Glauer, op. cit., pp. 330-331.

18 Second Vatican Counsil, Konstytucja o świętej liturgii, [in:] A. Filaber, Prawodawstwo muzyki liturgicznej, Warszawa 1998, pp. 37-41.

19 B. Kicinger, Wprowadzenie do adoracji Najświętszego Sakramentu i medytacji organowych prof. Juliana Gembalskiego, [in:] Muzyka w służbie Bogu i człowiekowi, F. Koenig (ed.), Gliwice 2006, pp. 49-50.

20 Vide: G. Poźniak, Pomoce dla organistów na Ślasku na przełomie XIX i XX wieku. Przyczynek do rozważań o muzyce instrumentalnej w liturgii, "Additamenta Musicologica Lublinensia" 5 (2009), pp. 149-159. 
Currently, it is difficult to state how many organ works were composed by Stein, what is caused by the lack of the catalogue and the fact that frequently the particular compositions were published together with other works without the opus number. Among his organ pieces there are:

- Taschenbuch für Orgelspieler Op. 6;

- Preludien-Buch für die Orgel Op. 10 (Kothe-Leobschütz) dedicated to the teacher of a teacher's seminary, Julius Gloger;

- Vier-Vorund Nachspiele Op. 17 (Kothe-Leobschütz) dedicated to the singing teacher in a gymnasium, Mr. Wegner;

- Neues Praeludienbuch für die Orgel Op. 23 (Kothe-Leobschütz) dedicated to the teacher of a teacher's seminary, Wilhelm Osburg;

- Charakterstücke für die Orgel Op. 31 (Kothe-Leobschütz) dedicated to the "beloved uncle-the organist in Prudnik-Ernst Stein";

- Tonstücke über Motive aus obigen Kirchenliedern Op. 40.

The usage and pedagogical character of the particular opus numbers is confirmed by their titles. As it has been mentioned before, musical education in the teacher's seminaries comprised studying the organ playing. Due to the model of liturgy the organists needed to have particular help, so highly qualified seminary teachers wrote compositions of the educational purpose, which could be successfully used also in celebration of the service. The excellent example for this can be Bruno Stein's chorale preludes based on the church songs (e.g. Komm, Geist und Schöpfer, kehre ein; Herzlich tut mich verlangen and others). Also, short preludes of a differentiated character became popular, in the most popular major and minor keys (Opus 10, Opus 23).

The separate section consists of Opus 17 and 31 . Opus 17 contains only four compositions, namely preludes and postludes. They have solemn character and demand a higher technical abilities as well as experience in the organ playing. Opus 31, on the other hand, is the collection of seven works written in different styles-there are such compositions as: 
1. Präludium in C minor;

2. Romanze in Ab major;

3 Canzonetta in G minor;

4. Intermezzo in F minor;

5. Traumgesicht in E major;

6. Chorale prelude $O$, Maria, sei gegrüßt in Eb major;

7. Postludium in E major.

The proof for the claim that Bruno Stein used the rich output of the great masters can be a short introduction of the composer to the Opus 23. Here is its fragment:

...Es ist wiederum versucht worden, Wohlklang und motivische Arbeit zu verbinden, das Studium von Brosig, M.G. Fischer und Bach vorzubereiten. Möge das Werk eine wohlwollende Aufnahmefinden!

Paradies, (Posen) im November 1902 21

Among organ notebooks published as help for organists, the name of Stein (both Bruno and his father Joseph) appears frequently. How appreciated was the son's work is confirmed by the fact that his compositions were published among the works of famous and musicians and composers, such as Emmanuel Adler, Sigfried Cichy, Moritz Brosig. At this moment it should be underlined that Bruno Stein's education and his pedagogical experience influenced the works that he composed-their solid compositional craft, motivic work, the use of the organ's possibilities, the ease of operating cantus firmus from the songs.

21 "Again we tried to join the pleasant sound with motivic work and to prepare the study on Brosig, M.G. Fischer and Bach. Take this work with kindness! Paradyż, November 1902". 


\section{Analysis of the chosen organ works}

The works discussed below can be divided into two groups. The first of them consists of organ chorales and the second one of chorale preludes. The term "prelude" is used for a form of a free character, often with different names (such as canzonetta, intermezzo, postludium, vorspiel etc.). In preludes such techniques were used as chords, figurations and imitation. Organ chorales are a separate group, in which a melody of a song is cantus firmus. ${ }^{22}$

\section{O Haupt voll Blut und Wunden (* Herzlich tut mich verlangen) Op. 40 No. 5}

Organ chorale O Haupt voll Blut und Wunden is a part of a bigger setting for church songs. Among several works that were chosen to analyse it is distinguished through the three-part structure. The composer used the melody of a song composed by Hans Leo Hassler (dated on 1601), known both in Lutheran and Catholic Church. ${ }^{23}$ What is more, this theme was frequently chosen by numerous composers. The great example can be setting written by Johann Sebastian Bach of a catalogue number BWV 727.

Bruno Stein clearly distinguished each of three parts:

1. Larghetto-setting with cantus firmus for two manuals with pedalboard obligato;

2. Sostenuto-a short variation using only flute voices;

3. Maestoso-for two manuals with pedalboards, with the composer's annotation: Mit starken Stimmen.

22 Vide: D. Szlagowska, Muzyka baroku, Gdańsk 1998, pp. 142-144; H. Ferguson, Prelude, [in:] The New Grove Dictionary of Music and Musicians, S. Sadie (ed.), Vol. 15, London 2001, pp. 210-212.

23 Vide: Śpiewnik ewangelicki, Międzykościelna Komisja Śpiewnikowa (eds.), 2nd ed., Bielsko-Biała 2008, p. 1260; Droga do nieba, Międzydiecezjalna Komisja ds. Liturgii, Duszpasterstwa Liturgicznego i Muzyki Kościelnej Diecezji Gliwickiej i Opolskiej (eds.), Opole 2006, p. 782. 


\section{Part 1: Larghetto}

In the first part, the composer gives the superior role to the left hand. Separating cantus firmus on a different manual, he achieves the impression of "solo song with accompaniment". The accompaniment in this case is created by middle voices, based on bass line, contrapuntal to the melody of a chant. At the very beginning the function of a left hand was underlined-there is a characteristic rhythmic ostinato, emphasised by the downbeat rests (Example 1).

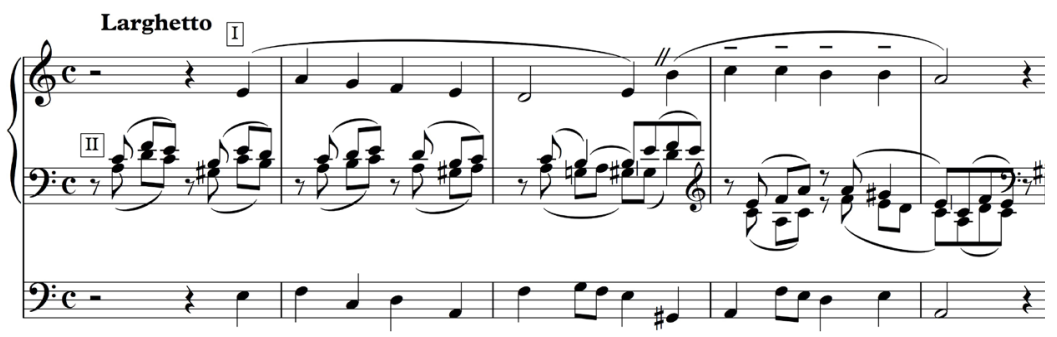

Ex. 1: B. Stein, O Haupt voll Blut und Wunden, fragment of a score, where all markings are visible, namely phrasing and articulation.

Harmonic schemes are based on dominant-tonic models, characteristic for the tonal system. The whole part is maintained in the key of A minor.

Melody and rhythm of cantus firmus are precisely taken from the original, composed by H.L. Hassler. Stein, paying attention to the pedagogical purpose of preludes, scrupulously noted all articulation marks. Slurring allows to precisely read phrasing and articulation. It should be noticed that the basic articulating technique that we should achieve is legato, and all exceptions were appropriately marked by the composer (caesuras, episemas, staccato dots, etc.).

\section{Part 2: Sostenuto}

Stein underlined the character of the second part through the title Sostenuto. Also, the commentary referring to the registers-Sanfte Flötenstimmen-makes no doubts about the way of performing it. 
Variations of cantus firmus allowed the composer to make changes in the melody line. What is more, after the closer examination it can be perceived that melody of this part was based on the motif of the first phrase of the chant O Haupt voll Blut und Wunden, modified in terms of rhythm (Example 2). As a factor which constructs the melodic line, Stein used also progressions.

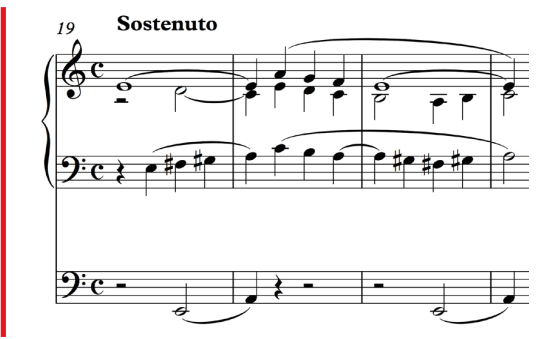

Ex. 2: B. Stein, O Haupt voll Blut und Wunden, melodic motif based on the tones $E A G F E$, being the sound material of the first phrase of a song.

Analogically to the first part, the remaining voices are the answer based on the structure of a tonal system, and downbeat rests postpone the sound of the full chord.

Motivic work is a technique thanks to which the composer through only one motif can make the composition more attractive. Stein interestingly uses the skip of a perfect fourth, being the interval, which begins the song O Haupt voll Blut und Wunden. The part of pedal contains four repetitions of it, which are a certain answer, having at the time the function of a root of a chord (edge of the bars: 1 and 2, 3 and 4, 5 and 6,10 and 11).

Despite using homophonic texture the particular voices can be, or even must be treated in the linear way, because they are the effect of motivic work.

\section{Part 3: Maestoso}

The last, third part uses the possibility of terraced dynamics through the change of manuals. The composers, similarly to the previous parts, wrote the interpretational hints in the score (Mit starken Stimmen, II. Werk schwächer), suggesting to use pleno of the main manual. 
Stein uses the various number of voices, doubling several elements to achieve the effect of a full sound. At the same time, he doubles the voice in which there is the melody of the chant in an octave. $^{24}$

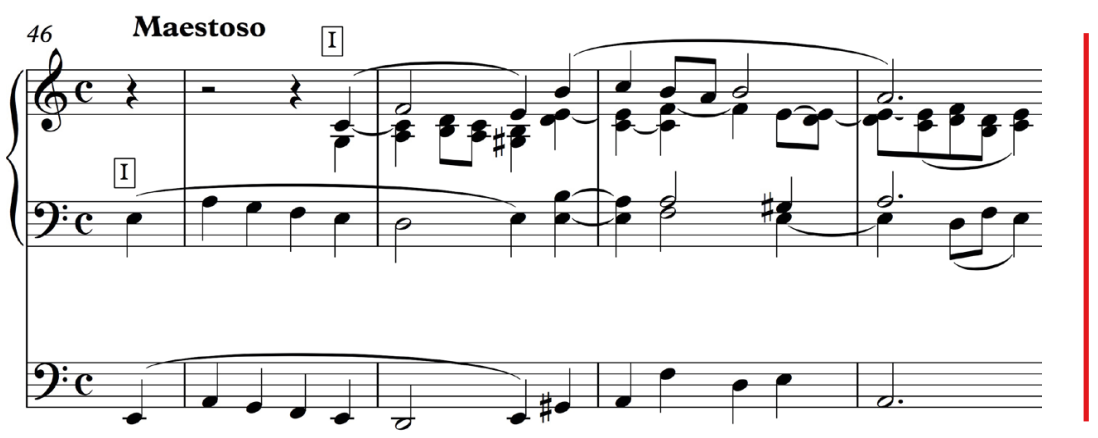

Ex. 3: B. Stein, O Haupt voll Blut und Wunden, beginning fragment of the third part of chorale prelude, in which melody of a song is shown in the part of left hand, doubled by pedalboard, and then moves to the highest voice.

What was characteristic for the second part was the fact that melody was based on the cantus firmus motif of the chant $O$ Haupt voll Blut und Wunden. Third part is similar in this aspect. The texture is created by the vertical structures and the tension is built through the seventh and ninth chords and suspensions.

As it has been mentioned above, the composer used the jump between manuals (bars 16-20), using the dynamic gradation in this part. The return to the main manual is a culmination and comes to the cadence beginning in the twenty-eighth bar and finishing in the thirty-second bar with a tonic chord in the root position.

From the presented analysis, we can assume that the organ chorale O Haupt voll Blut und Wunden Op. 40 No. 5 was composed as variations. The first part is the precise setting of the melody of H.L. Hassler's song and the presentation of a theme, which was developed in the following two parts.

24 Stein does not always put the melody of the chant in the highest voice. However, in order to better underline its structure, left hand has cantus firmus in unison with pedalboard (bars: $1-2,5-6$ ). 


\section{O, Maria, sei gegrüßt Op. 31 No. 6}

As a following work representing the cycle of organ chorales of Bruno Stein the author have chosen the prelude, which is the setting of the melody composed by him. ${ }^{25}$ What is interesting, in his composition for organ Stein places cantus firmus twice-for the first time in tenor, for the second in soprano-additionally placing there the text of the first and second strophe, somehow suggesting the possibility to use the instrumental work as a song's accompaniment.

The composer also noted that cantus firmus should be separated through playing it on a different manual. On the other hand, the part of pedalboard is characterised mainly by whole notes. The three-bar introduction indicates the character of the whole piece, at the same time presenting the leitmotif, which will accompany the melody of the song. Despite using the double metre, the listener has the impression of "waving" of the accompaniment, in which intervals of second and third dominate and ostinato rhythm only intensify this feeling.

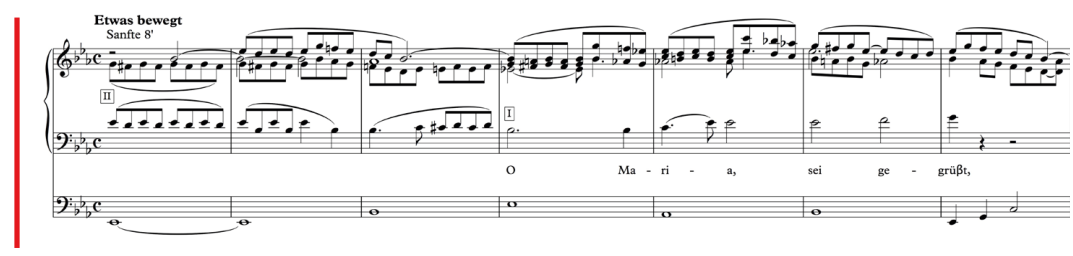

Ex. 4: B. Stein, O Maria, sei gegrüßt, first seven bars of the chorale prelude with a visible leitmotif and cantus firmus in tenor voice.

As it has been mentioned, the melody of a song is shown twice, separately for each strophe. After three bars of interlude (bars 20-22), which uses the musical material of the introduction,

25 In Kothe's edition there is the information that the source of the melody is the song for male choir a cappella, composed and edited by B. Stein. Vide: Charakterstücke für die Orgel. Sieben mittelschwer ausführbare Tonstücke zum Gebrauch bei Musikaufführungen komponiert von Bruno Stein, Opus 31, C. Kothe (ed.), Leobschütz 1913. 
cantus firmus moves from tenor voice to the highest voice. The second part of a piece is based on the same source of the melody, what provokes the use of similar models in accompaniment, and the bass base is not changed comparing to the first part. The whole part ends with the coda based on the pedal note $e b$, coming to the tonic chord.

In his chorale preludes Stein usually uses four-voice texture, but he is not attached to it, sometimes reducing it to three-voice texture, and sometimes doubling several elements with the aim to achieve a fuller sound. The precious hint for the beginning organists are also register marks. Although the composer avoids to precisely mark the particular sets of sounds, leaving the opportunity to choose the stops for the performer, he draws the way of using them, e.g. Sanfte 8', suggesting using soft, string-like 8' stop voices.

The text of the song composed by Stein, being the source of cantus firmus of a organ chorale $O$, Maria, sei gegrüßt Op. 31 No. 6:

O Maria, sei gegrüßt,

die du voller Gnade bist!

Sei gegrü $\beta$ t, du schönste

Zier,

Gott der Herr ist selbst mit dir.

Ave, ave, ave Maria, ave.

O Maria, Mutter mild,

sei du unser Schutz und Schild,

wenn wir sind in Todesnot,

bitte du für uns bei Gott.

Ave, ave, ave Maria, ave!
Oh Mary, be blessed

Full of grace!

Be blessed, the prettiest embellishment,

God is with You.

Ave, ave, ave Mary, ave.

Oh Mary, sweet Mother,

You are our escape and shield,

When Death approaches,

Pray for us to God,

Ave, ave, ave Mary, ave!

\begin{tabular}{|l|l|l|l|l|}
\hline Introduction & $\begin{array}{l}\text { Part I } \\
\text { (c.f. in tenor) }\end{array}$ & Bridge & $\begin{array}{l}\text { Part II } \\
\text { (c.f. in soprano) }\end{array}$ & End \\
\hline a & b & a1 & b1 & c \\
\hline bb. 1-3 & bb. 4-19 & bb. 20-22 & bb. 23-38 & bb. 39-44 \\
\hline
\end{tabular}

Table 2: Structure of the work. 
Vorspiel für zwei Manuale und Pedal Op. 17 No. 1

Opus 17 contains only four works. Analysing the whole collection, it can be seen as the culmination of Bruno Stein's organ output. The works comprising it are a synthesis of all compositional techniques that we could find in the previous compositions.

The first prelude is titled Vorspiel für zwei Manuale und Pedal. At the very beginning the tempo of the work and approximate indications concerning the registration are placed. The work starts with chords divided by eighth note rests, which have the function of a quasi-overture. The first fragment has thirty-two bars, but together with the fourth beat of the last bar the imitative part begins. The exposition is accompanied by contrapuntal voice, containing motivic material of a theme. Since the forty-second bar, the movement is introduced, received through breaking the basic quarter note rhythm. Certain complication of a work probably results from using figuration in the lowest voice, intended for pedalboard. At this moment the performer must show good technical preparation, as against the background of the bass voice there are additional chords in manual. Using a polyphonic texture requires linear thinking and, despite certain homophonic structures, horizontal lines of the voices are the most important. In his Op. 17 Stein reduces all marks, writing only phrasing and articulation for the most characteristic moments.

The seventy-sixth bar is the repetition of the first sixteen bars of the whole composition. As the part which was conventionally marked as second is finishing with the $B$ major chord (dominant in the key of $\mathrm{E}$ major), the repetition appears a major second above the principal key. The composer, after finishing this fragment, decides to use again the passages of eighth notes. He also introduces the progression and double octaves (also in the pedalboard), thickening the texture and at the same time achieving the full sound. Apogee takes place since the hundred-third bar. The culmination of means is linked with the beginning thematic-motivic material. The full pleno of the organ is cumulated by figuration and sharper articulation, and everything comes to the coda, based on the pedal note. 
Additionally, Stein yet after the final tonic chord decides to repeat it twice, until it sounds in the full way.

Vorspiel für zwei Manuale und Pedal is characterised by the solemn character. The composer does not tell us in which circumstances it should be played, but it can be concluded that he wanted it to appear at the beginning of the festive liturgy. The concert purpose also cannot be excluded. Analysed prelude, counting hundred and twenty-four bars, differs significantly from other works written with the pedagogical-usage purposes. Opus 17 claims to include the composition it contains to the repertoire of concerting organists. Used means and compositional techniques are the confirmation of Bruno Stein's solid craft and knowledge of composition as well as organ playing. The example of this can be the juxtaposition of the final fragment of Prelude with a fragment of fugue from Felix Mendelssohn's 2nd Organ Sonata Op. 65:

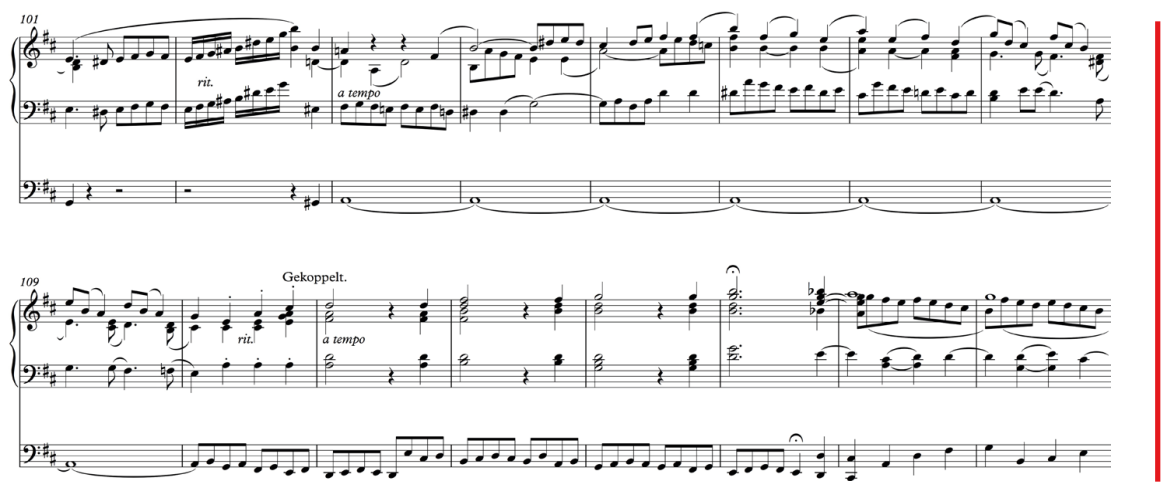



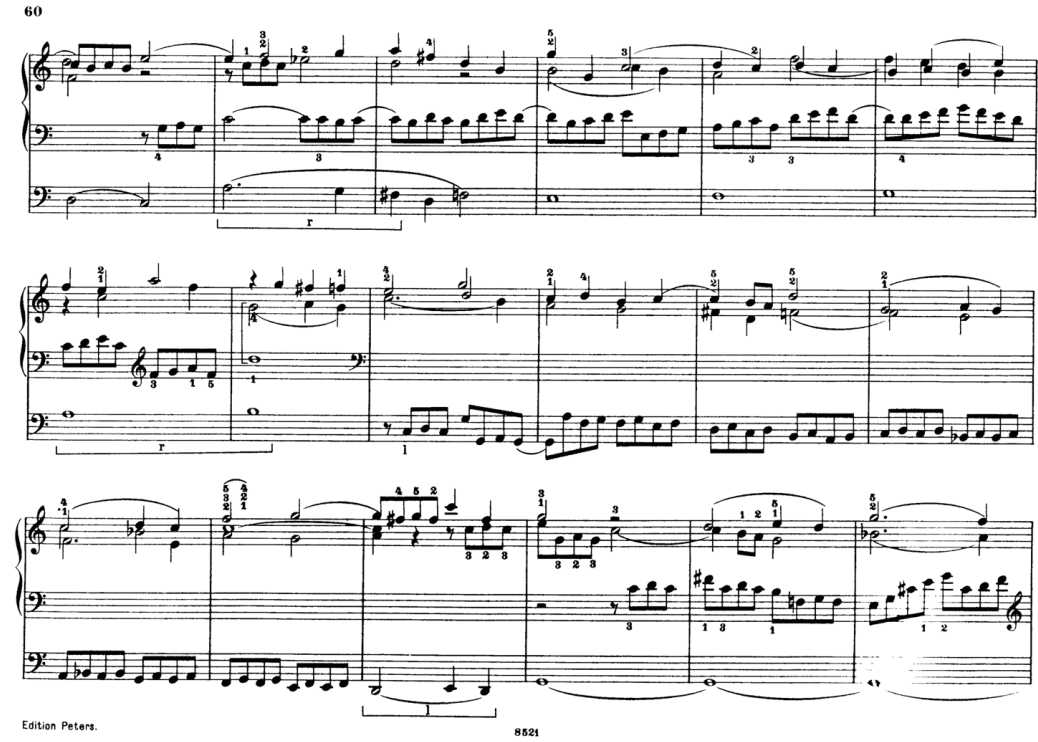

Ex. 5: B. Stein, Vorspiel für zwei Manuale und Pedal and Fugue from 2nd Organ Sonata Op. 65 by F. Mendelssohn. Similar compositional pre-requisites: moving the figuration from the manual to pedal, culminating thematic-motivic material.

\section{Conclusion}

In the article devoted to the Silesian organist and composer Bruno Stein, an attempt to display versatile workshop of the organistcomposer has been made. Based on Stein's activity, it can be assumed that this musician was one of the composers who through their actions influenced the development of church musicians and teachers animating musical life in their environments. Indeed, his persona was presented in this aspect. His popularity was primarily an effect of reliability and his knowledge. ${ }^{26}$ Adepts of organ art could successfully educate themselves from the compositions of

26 Articles about B. Stein and his own essays can be found, among others, in the journal "Cäcilia". Vide: "Cäcilia" 6 (1900), 7 (1900), 2 (1901), 4 (1902), 12 (1902), 1 (1905), 4 (1905), 6 (1905), 10 (1908), 1 (1909), 10 (1909), 11 (1919). 
his teacher. Without doubt, such a pedagogue became an authority for a student, having not only wide knowledge but also the practical skills. A musician, who reliably held the function of an organist, conductor and pedagogue could have impressed his pupils. How not to respect the teacher who knows the needs of a student? Bruno Stein tried to fulfil these needs for his whole life. The convincing proof for this is his output of seventy-five opus numbers.

\section{Bibliography}

Charakterstücke für die Orgel. Sieben mittelschwer ausführbare Tonstücke zum Gebrauch bei Musikaufführungen komponiert von Bruno Stein, Opus 31, C. Kothe (ed.), Leobschütz 1913.

Chrząszcz J., Historia miast Pyskowice i Toszek, Gliwice 1994.

Droga do nieba, Międzydiecezjalna Komisja ds. Liturgii, Duszpasterstwa Liturgicznego i Muzyki Kościelnej Diecezji Gliwickiej i Opolskiej (eds.), Opole 2006.

Filaber A., Prawodawstwo muzyki liturgicznej, Warszawa 1998.

Glauer A., 150 Jahre-eine Zeitreise, Opole 2012.

Glauer A., Kischnick K., Das höhere Schulwesen in der Stadt Rosenberg OS 1873-1944, Opole 2013.

Hamann F., Die Musikerziehung an den ehemaligen Lehrerseminaren in Nieder- und Oberschlesien, Ost- und Westpreußen, Pommern und Posen nebst Biographien ihrer Musiklehrer (SML), Dortmund 1976.

Jendrossek K., Zum Andenken an Bruno Stein, "Cäcilia" 1 (1916).

Kicinger B., Wprowadzenie do adoracji Najświętszego Sakramentu i medytacji organowych prof. Juliana Gembalskiego, [in:] Muzyka w służbie Bogu i człowiekowi, F. Koenig (ed.), Gliwice 2006.

Możdżeń S.I., Historia wychowania 1795-1918, Sandomierz 2006.

Neues Praeludienbuch für die Orgel. Enthaltend 35 mittelschwer ausführbare Orgelstücke in den gebräuchlichsten Dur- und Moll Tonarten komponiert von Bruno Stein, Opus 23, C. Kothe (ed.), Leobschütz [without year].

Poźniak G., „Pomoce dla organistów” na Ślasku na przełomie XIX i XX wieku. Przyczynek do rozważań o muzyce instrumentalnej w liturgii, "Additamenta Musicologica Lublinensia" 5 (2009). 
Preludien-Buch für die Orgel. Enthaltend 35 mittelschwer ausführbare Orgelstücke in den gebräuchlichsten Dur- und Moll Tonarten komponiert von Bruno Stein, Opus 10, C. Kothe (ed.), Leobschütz 1916.

Preparandy nauczycielskie, Ministerstwo Wyznań Religijnych i Oświecenia Publicznego (eds.), Warszawa 1922.

Sammlung instruktiver Vor- und Nachspiele zu den gebräuchlichsten Kirchenliedern der Diözese Breslau, K. Hoppe (ed.), Bytom [without year].

Schlesisches Musiklexikon, L. Hoffmann-Erbrecht (ed.), Augsburg 2001. Śpiewnik ewangelicki, Międzykościelna Komisja Śpiewnikowa (eds.), 2nd ed., Bielsko-Biała 2008.

Stein B., Kirchliche Singschulen, "Cäcilia" 2 (1901).

Stein B., Rücblick und Ausblick, "Cäcilia" 12 (1902).

Stein B., Ueber das Registieren, "Cäcilia" 6 (1900).

Stein B., Ueber das Registieren, "Cäcilia" 7 (1900).

Stein B., Wahre Kritik, "Cäcilia" 4 (1902).

Strecke G., Josef und Bruno Stein, zwei oberschlesischen Kirchenkomponisten, "Der Oberschlesier" 11 (1929).

Szlagowska D., Muzyka baroku, Gdańsk 1998.

The New Grove Dictionary of Music and Musicians, Vol. 15, S. Sadie (ed.), London 2001.

Vier Vor- und Nachspiele für volle Orgel komponiert von Bruno Stein, Königl. Seminarlehrer, Opus 17, C. Kothe (ed.), Leobschütz [without year].

\section{Online sources}

Dereń E., Kształcenie nauczycieli w Polsce, https://sites.google.com/site/ ksztalcenienauczycieli/organizacja-ksztalcenia-nauczycieli/lata-19181939/ [accessed: 18.03.2018].

Internetowy System Aktów Prawnych, http://isap.sejm.gov.pl/ [accessed: 18.03.2018]. 